JIIA, VOLUME 8 No. 2, MEI 2020

\title{
PENDAPATAN DAN TINGKAT KESEJAHTERAAN SUBJEKTIF KELUARGA PETANI ALIH KOMODITI PADI KE KARET DI KECAMATAN ABUNG SURAKARTA KABUPATEN LAMPUNG UTARA
}

\author{
(Income and Subjective Welfare Level of Farmer Households who Switch planting from Rice to Rubber in \\ Abung Surakarta Sub-District Lampung Utara District)
}

Ayu Sari Miswati, Dyah Aring Hepiana Lestari, dan Lina Marlina

Jurusan Agribisnis, Fakultas Pertanian, Universitas Lampung, Jl. Prof. Dr. Soemantri Brodjonegoro No. 1 Bandar Lampung 35145, Telp. 085768508919, e-mail: dyah.aring@fp.unila.ac.id

\begin{abstract}
This research aims to analyze the income of rubber plantation in the past year and the subjective welfare level of farmer household who switch commodity from rice plant to rubber in District of Abung Surakarta. This research was conducted in February-March 2019 using a survey method. The number of respondents was 56 farmers using simple random sampling technique. Data are analyzed using descriptive statistical methods and inferencing statistics and the analysis tools used are farm income and subjective welfare indicators using a Likert scale from strongly disagree to strongly agree. The results of the analys showed that the average income of rubber farming based on cash costs and the total costs are Rp27,821,627.65 / hectar / year and Rp18,357,350.60 / hectare / year. Farmer households are dominated by subjective welfare in high level criteria.
\end{abstract}

Key word: farming income, subjective welfare, transfer of commodity

\section{PENDAHULUAN}

Pertanian merupakan sektor yang memiliki peranan penting terhadap perekonomian Indonesia. Hal ini dikarenakan Indonesia memiliki cakupan yang luas terhadap sektor pertanian baik wilayah maupun perekonomiannya. Pada tahun 2016 subsektor yang berkontribusi besar dalam sektor pertanian adalah tanaman perkebunan sebesar $27,24 \%$ dan tanaman pangan sebesar 25,46\% (BPS 2018). Tingginya kontribusi tanaman perkebunan terhadap perekonomian disebabkan produksi perkebunan lebih tinggi dibanding dengan tanaman pangan atau tanaman lainnya. Salah satu tanaman perkebunan dengan produksi tinggi adalah tanaman karet yang menempati urutan ke 2 setelah kelapa sawit (Kementerian Pertanian 2017).

Pada tahun 2016 harga karet mencapai Rp10.852,00/kg, permintaan dalam negeri sebesar 60,871 ribu ton, serta ekspor sebesar 2,58 juta ton. Salah satu upaya untuk memenuhi permintaan dari dalam dan luar negeri yaitu melalui peningkatan produksi dengan memperluas areal tanam perkebunan karet. Harga dan permintaan karet yang relatif tinggi tersebut mendorong petani melakukan alih komoditi dari tanaman non karet menjadi tanaman karet, termasuk tanaman padi yang dinilai dapat meningkatkan pendapatan petani
(Armin 2017). Adanya Undang-undang No 41 Tahun 2009 tentang Perlindungan Lahan Pertanian Pangan Berkelanjutan tidak membuat petani enggan melakukan alih komoditi tanaman pangan (padi) menjadi tanaman non pangan (perkebunan) karena petani menginginkan pendapatan yang tinggi. Alih fungsi lahan atau alih komoditi merupakan berubahnya sebagian atau keseluruhan penggunaan lahan awal kepada fungsi lain yang memiliki dampak negatif terhadap lingkungan maupun lahan itu sendiri (Irawan 2005).

Alih komoditi juga terjadi di Kabupaten Lampung Utara. Data menunjukkan Kabupaten Lampung Utara mengalami penurunan luas lahan sawah sebesar 39,18\% dan peningkatan luas lahan karet sebesar 92,19\% (BPS Kabupaten Lampung Utara 2016). Menurut Sari, Ismono dan Kasymir (2015), saluran irigasi yang tersedia di Provinsi Lampung terdapat cukup banyak, namun tidak digunakan secara maksimal karena air irigasi tidak cukup untuk mengairi tanaman padi sehingga banyak petani melakukan alih komoditi dari tanaman padi ke tanaman lain.

Kecamatan Abung Surakarta merupakan salah satu kecamatan yang berkontribusi besar dalam hal tersebut. Kecamatan Abung Surakarta mengalami penurunan luas lahan sawah yang sangat besar. 
Penurunan luas lahan sawah dari tahun 2010 sampai 2016 ini mencapai 646,25 Ha atau sebesar $20,81 \%$, sedangkan luasan lahan perkebunan karet dari tahun 2010 sampai 2016 meningkat sebesar $1.207 \mathrm{Ha}$ atau sebesar $447 \%$. Selain disebabkan oleh faktor irigasi, alih komoditi juga dilakukan oleh petani dengan tujuan memperoleh pendapatan yang tinggi.

Menurut Alhidayad (2008) upaya peningkatan pendapatan petani secara nyata tidak selalu diikuti dengan peningkatan kesejahteraan petani. Kecamatan Abung Surakarta menempati urutan ke 16 sebagai kecamatan dengan kategori keluarga pra-sejahtera terbanyak dari total 23 kecamatan yang ada di Lampung Utara (BPS Kabupaten Lampung Utara 2016). Hal tersebut menandakan bahwa tingkat kesejahteraan di Kecamatan Abung Surakarta masih rendah walaupun melakukan alih komoditi tertinggi dibanding kecamatan lainnya.

Penilaian kesejahteraan suatu individu dapat dilihat dengan pendekatan objektif dan subjektif. Menurut Mardiana, Abidin, dan Soelaiman (2014) kesejahteraan dengan pendekatan objektif dapat diukur menggunakan indikator kesejahteraan BPS (2009), indikator kemiskinan menurut Sajogyo (1997) atau beberapa indikator lain yang menilai kesejahteraan berdasarkan pemenuhan kebutuhan fisik minimum. Berbeda dengan kesejahteraan pendekatan objektif, kesejahteraan subjektif merupakan evaluasi secara kognitif dan emosi seseorang terhadap kehidupannya sendiri (Diener 2000). Penelitian ini menggunakan pendekatan subjektif dalam menilai kesejahteraan, hal tersebut dilakukan dengan pertimbangan bahwa pendekatan objektif telah banyak dilakukan oleh peneliti sebelumnya, sedangkan pendekatan subjektif masih jarang dilakukan. Tujuan penelitian ini adalah untuk menganalisis pendapatan usahatani karet pada tahun 2018 dan menganalisis tingkat kesejahteraan subjektif keluarga petani.

\section{METODE PENELITIAN}

Penelitian dilakukan dengan metode survei. Lokasi penelitian di Kecamatan Abung Surakarta, Kabupaten Lampung Utara yang dipilih secara sengaja (purposive). Pengambilan data dilaksanakan pada bulan Februari hingga Maret 2019. Responden penelitian adalah petani yang melakukan alih komoditi dari tanaman padi ke karet di Desa Karya Sakti, Bandar Sakti, dan Purba Sakti. Teknik pengambilan sampel yang digunakan adalah simple random sampling. Populasi petani yang melakukan alih komoditi dari padi ke karet ini berjumlah 202 kepala keluarga. Penentuan jumlah sampel mengacu pada Issac dan Michael dalam (Sugiarto 2003) yaitu:

$$
\mathrm{n}=\frac{\mathrm{NZ}^{2} \mathrm{~S}^{2}}{\mathrm{Nd}^{2}+\mathrm{Z}^{2} \mathrm{~S}^{2}}
$$

Keterangan:

$$
\begin{aligned}
\mathrm{n} & =\text { Jumlah sampel } \\
\mathrm{N} & =\text { Jumlah populasi petani alih komoditi } \\
& \text { padi ke karet }(202) \\
\mathrm{S}^{2} & =\text { Variasi sampel }(5 \%=0,05) \\
\mathrm{Z} & =\text { Derajat kepercayaan }(95 \%=1,96) \\
\mathrm{d} & =
\end{aligned}
$$

Berdasarkan perhitungan dengan rumus tersebut, maka diperoleh jumlah sampel sebanyak 56 petani, dengan masing-masing Desa Karya Sakti 21 petani, Purba Sakti 18 petani, dan Bandar Sakti 17 petani yang ditentukan berdasarkan rumus penentuan sampel secara proporsional, yaitu:

$$
\mathrm{Ni}=\frac{\mathrm{Ni} \cdot \mathrm{n}}{\mathrm{N}}
$$

Keterangan:

$$
\begin{array}{ll}
\mathrm{ni} & =\text { Jumlah responden desa ke } \mathrm{i} \\
\mathrm{Ni} & =\text { Jumlah sub populasi desa ke } \mathrm{i} \\
\mathrm{n} & =\text { Jumlah sampel } \\
\mathrm{N} & =\text { Jumlah populasi }
\end{array}
$$

Data yang digunakan dalam penelitian berupa data primer dan data sekunder. Data primer diperoleh dari wawancara langsung dan data sekunder diperoleh dari Dinas Pertanian, Badan Pusat Statistik, dan Badan Penyuluh Pertanian Kecamatan Abung Surakarta.

Penelitian ini menggunakan analisis deskriptif kuantitatif. Metode tersebut digunakan untuk menghitung pendapatan usahatani karet dan tingkat kesejahteraan subjektif keluarga petani.

\section{Analisis Pendapatan Usahatani Karet}

Pendapatan usahatani karet satu tahun terakhir dihitung menggunakan rumus Soekartawi (2002) yaitu:

$$
\pi=\text { Y. Py }-\Sigma \text { Xi.Pxi. }
$$

Keterangan :

$\pi=$ Pendapatan usahatani satu tahun terakhir (Rp)

$\mathrm{Y}=$ Jumlah produksi satu tahun terakhir $(\mathrm{kg}$ getah segar)

Py $\quad=$ Harga satuan produksi satu tahun terakhir $(\mathrm{Rp} / \mathrm{kg})$

$\mathrm{X}=$ Faktor produksi satu tahun terakhir (satuan) 
Px = Harga faktor produksi satu tahun terakhir (Rp/satuan)

\section{Analisis Kesejahteraan Subjektif Petani Alih Komoditi}

Tingkat kesejahteraan subjektif diukur dengan beberapa indikator yang terdiri dari beberapa pertanyaan. Menurut Rahma, Puspitawati, dan Herawati (2015) indikator tersebut meliputi : 1) komponen pertanyaan indikator kesejahteraan fisik yang terdiri dari kepuasan terhadap makanan keluarga, kebersihan di dalam rumah, ketersediaan tempat pembuangan sampah, kesehatan diri dan keluarga, manajemen pekerjaan, keadaan air, kondisi tempat penampungan air, dan saluran air. 2) Indikator kesejahteraan ekonomi meliputi terdiri dari keuangan, keadaan pendapatan, keadaan tempat tinggal dan aset, kepemilikan lahan pertanian, hasil panen pertanian, kondisi usahatani, manajemen keuangan, pakaian keluarga, pakaian responden, serta fasilitas dan alat-alat pertanian. 3) Indikator kesejahteraan sosial berkaitan dengan keadaan pendidikan anak, akses informasi terkait penyuluhan, keterlibatan pasangan responden dalam penyuluhan pertanian, keadaan pekerjaan, manajemen waktu, hubungan sosial dengan pasangan responden, saudara, orangtua, anak, tetangga serta dukungan sosial yang diberikan oleh pasangan, saudara, orangtua, anak atau tetangga . 4) Indikator kesejahteraan psikologi mencakup keadaan spiritual, keadaan mental keluarga, pengetahuan mengenai sanitasi lingkungan, perilaku anak, pengetahuan dan keterampilan pasangan di bidang pertanian, dan optimisme keluarga tentang kehidupan masa depan.

5) Indikator kondisi pekarangan dinilai berdasarkan kepuasan terhadap kondisi, variasi tanaman, pendapatan, dan kebersihan pekarangan. 6) Indikator kondisi kebun dinilai berdasarkan kepuasan terhadap pendapatan kebun, manajemen pestisida, hasil penggunaan pestisida dan ketidakpastian musim dan iklim.

Selain menggunakan 6 indikator menurut Rahma et al. (2015) penelitian ini juga menggunakan 2 indikator menurut Diener (2000) yaitu: 1) Dimensi afektif ditekankan pada pengalaman emosi petani, baik yang bersifat positif atau senang dan bersifat negatif atau tidak senang. 2) Dimensi kognitif berkaitan dengan kepuasan alih komoditi terhadap kemampuan dan pengetahuan yang dimiliki. Kepuasan ini berkaitan dengan kemampuan petani dalam menjalani usahatani karet (usahatani baru) dan juga kepuasan terhadap hasil usahatani karet yang dinilai sesuai dengan ilmu pengetahuan yang dimiliki.

Sebanyak 43 pertanyaan mengenai tingkat kesejahteraan subjektif diukur menggunakan skala Likert dari 1 sampai 5. Angka 1 menunjukkan jawaban sangat tidak setuju yang artinya tingkat kesejahteraan keluarga petani sangat rendah, angka 2 menunjukkan jawaban tidak setuju yang artinya tingkat kesejahteraan keluarga petani rendah, angka 3 menunjukkan jawaban petani ragu-ragu yang artinya tingkat kesejahteraan keluarga petani sedang, angka 4 menunjukkan jawaban setuju yang artinya tingkat kesejahteraan keluarga petani tinggi, dan angka 5 menunjukkan jawaban sangat setuju yang artinya tingkat kesejahteraan keluarga petani sangat tinggi. Hasil uji validitas menunjukkan nilai corrected item-total correlation lebih besar dari 0,2 , sehingga semua pertanyaan dalam kuesioner telah valid. Hasil uji reliabilitas menunjukkan nilai cronbach alpha sebesar 0,957 artinya lebih dari 0,6 , sehingga diambil kesimpulan bahwa kuesioner telah reliable (Sufren dan Natanael (2013). Pengukuran tingkat kesejahteraan dinilai berdasarkan modus data yang sering muncul.

\section{HASIL DAN PEMBAHASAN}

\section{Karakteristik Responden}

Umur responden petani alih komoditi dari padi ke karet di Kecamatan Abung Surakarta Kabupaten Lampung Utara antara 40-60 tahun (66,07\%). Hal ini menunjukkan bahwa hampir seluruh penduduk berada pada umur produktif. Tingkat pendidikan sebagian besar petani alih komoditi ialah lulusan SD dengan jumlah 19 orang $(33,93 \%)$. Luas lahan karet garapan petani berkisar antara 0,25-0,67 Ha $(51,79 \%)$ dengan umur karet berkisar antara $8-9$ tahun $(53,57 \%)$ yang berarti bahwa kondisi karet mampu menghasilkan lateks dengan produksi tinggi Damanik et al. (2010). Mayoritas petani memiliki pengalaman usahatani kurang dari 10 tahun (51,79\%). Jumlah tanggungan keluarga petani terbanyak adalah 2-4 $(82,14 \%)$ dengan ratarata 4 jiwa per keluarga.

\section{Penggunaan Input Usahatani Karet}

Salah satu input yang sangat penting dalam menjalankan suatu usahatani adalah lahan. Sewa lahan termasuk ke dalam biaya diperhitungkan jika lahan tersebut merupakan lahan milik sendiri. Hal tersebut dikarenakan petani tidak mengeluarkan uang secara tunai untuk menyewa lahan, namun 
sebenarnya petani mengorbankan lahannya sehingga tidak dapat digunakan untuk kegiatan lainnya. Sewa lahan pertanian khususnya perkebunan di Kecamatan Abung Surakarta Kabupaten Lampung Utara mencapai Rp8.000.000,00/ha/th, sehingga besarnya biaya sewa lahan yang ditanggung oleh petani responden tergantung luas lahan yang dimilikinya. Rata-rata luas lahan yang dimiliki oleh petani responden adalah sebesar $0,71 \mathrm{Ha}$ atau dikenai biaya sewa lahan sebesar Rp5.680.000,00/th.

Pupuk merupakan salah satu input yang selalu digunakan oleh petani dalam menjalankan suatu usahatani. Pupuk yang digunakan oleh petani beragam, mulai dari pupuk Urea, NPK, SP, kandang, TSP, KCl, Organik, ZA, Phonska, sampai kapur tanah. Jenis pupuk yang digunakan oleh petani banyak yang berbeda, hal ini dikarenakan kemampuan ekonomi petani dalam membeli pupuk juga berbeda-beda, serta kebutuhan tanaman karet perhektar yang dimiliki petani juga berbedabeda (jumlah pohon berbeda). Biaya rata-rata untuk pupuk adalah sebesar Rp1.469.888,14/ha/th.

Pestisida atau obat-obatan yang digunakan oleh petani karet hanya herbisida yang digunakan untuk membasmi atau mengurangi gulma. Beberapa herbisida yang digunakan oleh petani karet adalah Clean Up, Paratop, Round Up, Boral, dan Gramaxone. Petani responden menggunakan berbagai merk dagang pestisida disesuaikan dengan kebutuhan dalam membasmi gulma. Biaya pestisida adalah sebesar Rp285.388,85/ha/th.

Alat-alat pertanian yang utama dalam menjalankan usahatani karet yaitu pisau sadap, mangkuk getah karet, dan talang getah karet sebagai pengalir getah dari batang ke mangkuk, sedangkan alat pertanian tambahannya berupa cangkul, koret, arit, golok, dan sprayer. Biaya rata-rata penyusutan alat pertanian adalah sebesar Rp433.696,20/ha/th.

Tenaga kerja yang digunakan dalam usahatani tanaman karet berasal dari dalam dan luar keluarga. Tenaga kerja yang berasal dari luar keluarga dikenai upah langsung yang dihitung dalam biaya tunai, sedangkan tenaga kerja yang berasal dari dalam keluarga tidak dikenai upah secara langsung, sehingga input ini perlu dimasukkan dalam biaya yang diperhitungkan. Upah tenaga kerja yang berlaku di Kecamatan Abung Surakarta adalah Rp33.000,00/6 jam kerja. Biaya rata-rata tenaga kerja luar keluarga adalah sebesar Rp34.029,18/ha/th dan tenaga kerja keluarga sebesar Rp9.923.654,43/ha/th. Rendahnya biaya tenaga kerja yang dikeluarkan oleh petani karet dikarenakan hanya ada beberapa petani saja yang menggunakan tenaga kerja luar keluarga dalam menjalankan kegiatan usahatani karet.

\section{Produksi Usahatani Karet}

Produksi lateks yang dihasilkan oleh tanaman karet di Kecamatan Abung Surakarta Kabupaten Lampung Utara umumnya dipanen setiap 2 sampai 4 hari atau jika lateks telah memenuhi mangkuk yang disediakan sebagai penampung lateks di setiap batang pohon karet dalam satu tahun. Lateks yang dihasilkan akan berbeda antar petani dikarenakan perbedaan varietas tanaman yang di budidayakan yaitu IRR 32, IRR 39, dan IRR 118. Selain itu, perbedaan hasil lateks yang didapatkan oleh petani juga disebabkan perawatan, dan proses penyadapan yang berbeda. Perbedaan proses perawatan yang dilakukan petani mencakup proses pemupukan dan pemberantasan gulma, ada yang melakukan pemupukan hanya sekali, namun ada juga yang sampai 4 kali dalam setahun, begitu juga halnya dalam pemberantasan gulma ada yang sekali, bahkan ada yang sampai 3 kali dalam setahun. Selain itu, setiap responden memiliki proses penyadapan dengan waktu dan cara sadap juga berbeda.

Lateks yang dihasilkan oleh petani dijual dalam kondisi mentah memiliki kandungan 25-40\% bahan karet mentah (crude rubber) dan $60-75 \%$ serum (air dan zat yang larut) dengan hasil produksi sebesar 8,81 ton/ha/th. Produksi getah karet segar petani Kecamatan Abung Surakarta setara lateks kering adalah sebesar 2,3 ton/ha/th (angka konversi 0,26). Hasil produksi ini berbeda dengan produksi potensial karet sebesar 2,5 ton/ha/th lateks kering (Triwijoso dan Utami 1995). Lateks kering ini mengandung 90-95\% karet murni, $2-3 \%$ protein dan $1-2 \%$ asam lemak, $0,2 \%$ gula, $0,5 \%$ garam dari $\mathrm{Na}, \mathrm{K}, \mathrm{Mg}, \mathrm{P}, \mathrm{Ca}, \mathrm{Cu}$, $\mathrm{Mn}$, dan Fe.

Perbedaan hasil produksi karet di Kecamatan Abung Surakarta dengan produksi potensial lateks per hektar disebabkan petani menanam tanaman karet dengan jarak yang jauh berbeda dengan panduan teknis. Menurut Astuti, Wibawa dan Ishak (2014) jarak tanam yang dianjurkan untuk menanam karet adalah $3 \times 6 \mathrm{~m}, 4 \times 5 \mathrm{~m}$, atau $3,5 \times$ $5,5 \mathrm{~m}$, sedangkan jarak tanam yang digunakan oleh petani responden adalah $3 \times 2,5 \mathrm{~m}$ dan $2 \times 3 \mathrm{~m}$. Pertimbangan yang dilakukan petani menanam tanaman karet dengan jarak yang lebih dekat dikarenakan banyak tanaman karet yang tidak bisa 
disadap karena cacat (mati getah). Akibat dari jumlah tanaman yang ditanam terlalu banyak mempengaruhi pertumbuhan karet itu sendiri dan terjadi persaingan dalam memperoleh zat-zat tumbuh dan air dari dalam tanah.

\section{Analisis Pendapatan Usahatani Karet}

Harga dan produksi yang diterima petani dapat mempengaruhi penerimaan yang didapatkan, dengan biaya yang dikeluarkan sama atau tetap, sedangkan hasil produksi dan harga jual yang tinggi, maka akan meningkatkan pendapatan petani. Harga yang diterima petani bervariasi antara Rp4.520,00-Rp6.250,00/Kg, tergantung kualitas getah karet yang dijualnya. Rata-rata penerimaan, biaya, dan pendapatan usahatani karet dapat dilihat pada Tabel 1 .
Pendapatan usahatani karet dihitung berdasarkan biaya tunai dan biaya total yang keluarkan oleh petani pada tahun 2018. Input-input yang termasuk dalam biaya tunai meliputi biaya penggunaan pupuk, biaya pestisida, biaya bahan bakar transportasi dan tawas, upah tenaga kerja luar kelurga, serta pajak, sedangkan input-input yang digolongkan ke dalam biaya diperhitungkan antara lain biaya upah tenaga kerja keluarga, penyusutan alat pertanian, serta sewa lahan. Usahatani karet di Kecamatan Abung Surakarta Kabupaten Lampung Utara memiliki penerimaan sebesar Rp49.760.961,72/ha/th dengan rata-rata biaya tunai dan biaya total yang dikeluarkan terhadap usahatani karet sebesar Rp3.581.983,45/ha/th dan Rp21.939.334,08/ha/th.

Tabel 1. Rata-rata penerimaan, biaya, dan pendapatan usahatani karet tahun 2018 di Kecamatan Abung Surakarta Kabupaten Lampung Utara

\begin{tabular}{|c|c|c|c|c|c|c|c|}
\hline \multirow{2}{*}{ No } & \multirow{2}{*}{ Uraian } & \multirow{2}{*}{ Satuan } & \multirow{2}{*}{$\begin{array}{c}\text { Harga } \\
\text { (Rp)/satuan }\end{array}$} & \multicolumn{2}{|c|}{ Per Usahatani $(0,71 \mathrm{Ha})$} & \multicolumn{2}{|c|}{ Per $\mathrm{Ha}$} \\
\hline & & & & Jumlah & Nilai (Rp) & Jumlah & Nilai (Rp) \\
\hline \multirow[t]{2}{*}{1} & Penerimaan & & & & $35.330 .282,82$ & & $49.760 .961,72$ \\
\hline & Produksi getah karet & $\mathrm{kg}$ & $5.862,68$ & $6.026,30$ & $35.330 .282,82$ & $8.487,74$ & $49.760 .961,72$ \\
\hline \multirow[t]{30}{*}{2} & Biaya Produksi & & & & & & \\
\hline & Pupuk & & & & $1.043 .620,58$ & & $1.469 .888,14$ \\
\hline & Pupuk Urea & $\mathrm{kg}$ & $1.973,08$ & 205,06 & $404.597,04$ & 288,82 & $569.854,99$ \\
\hline & Pupuk NPK & $\mathrm{kg}$ & $6.650,00$ & 8,93 & $59.375,00$ & 12,58 & $83.626,76$ \\
\hline & Pupuk SP & $\mathrm{kg}$ & $2.266,67$ & 9,23 & $20.910,00$ & 12,99 & $29.450,70$ \\
\hline & Pupuk Kandang & $\mathrm{kg}$ & 855,56 & 71,43 & $61.111,19$ & 100,60 & $86.072,10$ \\
\hline & Pupuk TSP & $\mathrm{kg}$ & $2.837,50$ & 31,25 & $88.671,88$ & 44,01 & $124.889,96$ \\
\hline & Pupuk KCl & $\mathrm{kg}$ & $5.961,54$ & 37,50 & $223.557,69$ & 52,82 & $314.869,99$ \\
\hline & Pupuk Organik & $\mathrm{kg}$ & 500,00 & 5,36 & $2.678,57$ & 7,55 & $3.772,64$ \\
\hline & Pupuk ZA & $\mathrm{kg}$ & $1.600,00$ & 2,68 & $4.285,71$ & 3,77 & $6.036,22$ \\
\hline & Pupuk Ponska & $\mathrm{kg}$ & $3.088,89$ & 55,74 & $172.183,49$ & 78,51 & $242.511,96$ \\
\hline & Kapur Tanah & $\mathrm{kg}$ & $1.000,00$ & 6,25 & $6.250,00$ & 8,80 & $8.802,82$ \\
\hline & Obat-obatan & & & & $202.626,08$ & & $285.388,85$ \\
\hline & Clean Up & lt & $57.142,86$ & 0,25 & $14.285,71$ & 0,35 & $20.120,72$ \\
\hline & Paratop & & $62.741,94$ & 2,02 & $126.604,26$ & 2,84 & $178.315,86$ \\
\hline & Round Up & lt & $76.428,57$ & 0,38 & $28.660,71$ & 0,53 & $40.367,20$ \\
\hline & Boral & lt & $70.000,00$ & 0,04 & $2.500,00$ & 0,05 & $3.521,13$ \\
\hline & Gramaxone & lt & $74.444,44$ & 0,41 & $30.575,40$ & 0,58 & $43.063,94$ \\
\hline & Biaya Lain-lain & & & & $1.270 .489,41$ & & $1.789 .421,71$ \\
\hline & Transportasi (BBM) & lt & $10.478,18$ & 82,37 & $863.097,50$ & 116,02 & $1.215 .630,29$ \\
\hline & Tawas & $\mathrm{kg}$ & $3.994,97$ & 101,98 & $407.391,91$ & 143,63 & $573.791,42$ \\
\hline & TK Luar Keluarga & HOK & $33.000,00$ & 0,73 & $24.160,71$ & 1,03 & $34.029,18$ \\
\hline & Pajak & $\mathrm{Rp}$ & $50.000,00$ & 0,71 & $35.500,00$ & & $50.000,00$ \\
\hline & Total biaya tunai & $\mathrm{Rp}$ & & & $2.543 .208,25$ & & $3.581 .983,45$ \\
\hline & Biaya Diperhitungkan & & & & & & \\
\hline & TK Keluarga & $\mathrm{HOK}$ & $33.000,00$ & 213,51 & 7.045.794,64 & 300,72 & $9.923 .654,43$ \\
\hline & Penyusutan Alat & (Rp/th) & & & $307.924,30$ & & $433.696,20$ \\
\hline & Sewa Lahan & $\mathrm{Rp} / \mathrm{th}$ & $8.000 .000,00$ & 0,71 & $5.680 .000,00$ & 1,00 & $8.000 .000,00$ \\
\hline & Total Biaya Diperhitungkan & $\mathrm{Rp}$ & & & $13.033 .718,95$ & & $18.357 .350,63$ \\
\hline & Total Biaya Produksi & $\mathrm{Rp}$ & & & 15.576.927,20 & & 21.939.334,08 \\
\hline \multirow[t]{2}{*}{3} & Pendapatan atas Biaya Tunai & $\mathrm{Rp}$ & & & $32.787 .074,57$ & & $46.178 .978,27$ \\
\hline & Pendapatan atas Biaya Total & $\mathrm{Rp}$ & & & $19.753 .355,63$ & & $27.821 .627,65$ \\
\hline
\end{tabular}


Biaya total yang dikeluarkan petani dalam usahatani karet di Kecamatan Abung Surakarta sangat tinggi dibandingkan dengan biaya tunai. Hal ini dikarenakan petani karet di Kecamatan Abung Surakarta sebagian besar menggunakan tenaga kerja dalam keluarga dan memiliki nilai sewa lahan diperhitungkan yang tinggi. Penerimaan berdasarkan produksi potensial karet seharusnya sebesar Rp55.695.460,00 (Triwijoso et al. 1995) dengan rata-rata harga lateks Rp5.862,68, namun produksi karet di Kecamatan Abung Surakarta berada di bawah produksi potensial, sehingga penerimaan yang didapatkan oleh petani pun berada di bawah penerimaan potensial. Rata-rata pendapatan usahatani karet atas biaya tunai sebesar Rp46.178.978,27/ha/th, sedangkan pendapatan atas biaya total $\mathrm{Rp} 27.821 .627,65 / \mathrm{ha} / \mathrm{th}$. Selisih antara pendapatan atas biaya tunai dan biaya total ini mencapai Rp18.357.350,60/ha/th.

Hasil penelitian di Kecamatan Abung Surakarta Kabupaten Lampung Utara berbeda dengan penelitian yang dilakukan oleh Mardiana et al (2014) dimana pendapatan atas biaya tunai dan biaya total tidak memiliki selisih yang jauh berbeda yakni sebesar Rp3.860.980,39/ha/th dengan pendapatan atas biaya tunai dan biaya total sebesar Rp18.117.623,53/ha/th dan Rp14.256.643,14/ha/th. Selisih yang tidak terlalu tinggi antara pendapatan atas biaya tunai dan pendapatan atas biaya total tersebut dikarenakan tenaga kerja keluarga yang digunakan tidak banyak dan sewa lahannya tidak termasuk dalam biaya diperhitungkan.

\section{Analisis Kesejahteraan Subjektif Petani}

Kesejahteraan subjektif merupakan kondisi dan kelayakan kehidupan yang dinilai oleh dirinya sendiri. Keluarga petani alih komoditi di Kecamatan Abung Surakarta memiliki total skor jawaban yang berbeda-beda. Hal ini dikarenakan petani memiliki tekanan kondisi fisik, ekonomi, sosial, psikis, serta kondisi penunjang seperti kebun dan pekarangan, dimensi kognitif (pengalaman emosi), dan dimensi kognitif (kemampuan dan pengetahuan) seseorang tidaklah sama. Sebanyak 43 pertanyaan yang diajukan kepada petani memiliki total skor antara 43-215. Modus skor jawaban yang diberikan oleh petani responden berdasarkan pertanyaan yang diajukan terkait kesejahteraan subjektif keluarga petani yang melakukan alih komoditi padi ke karet di Kecamatan Abung Surakarta Kabupaten Lampung Utara dapat dilihat pada Tabel 2.
Tabel 2. Modus skor jawaban petani terhadap tingkat kesejahteraan subjektif keluarga alih komoditi

\begin{tabular}{lc}
\hline Indikator & Modus Skor \\
\hline Kesejahteraan fisik & 4 \\
Kesejahteraan ekonomi & 4 \\
Kesejahteraan sosial & 4 \\
Kesejahteraan psikologi & 4 \\
Kondisi pekarangan & 3 \\
Kondisi kebun & 4 \\
Dimensi afektif & 3 \\
Dimensi kognitif & 4 \\
\hline
\end{tabular}

Indikator kesejahteraan fisik yang terdiri dari delapan pertanyaan yaitu mengenai kepuasan terhadap kondisi makanan sehari-hari, kebersihan rumah, ketersediaan tempat pembuangan sampah, kesehatan diri dan keluarga, kemampuan manajemen pekerjaan, kondisi air, tempat penampungan air, dan kondisi saluran air memiliki modus skor $=4$. Hal ini memberikan pengertian bahwa tingkat kesejahteraan subjektif keluarga petani didominasi oleh kesejahteraan tingkat tinggi berdasarkan penilaian indikator kesejahteraan fisik.

Indikator kesejahteraan ekonomi yang terdiri dari 11 pertanyaan mencakup kepuasan terhadap keuangan keluarga, keadaan pendapatan keluarga, tempat tinggal, aset keluarga, kepemilikan lahan pertanian, hasil pertanian, kondisi usahatani, manajemen keuangan, pakaian keluarga, pakaian petani, serta fasilitas dan alat-alat pertanian memiliki modus skor $=4$. Hal ini memberikan pengertian bahwa tingkat kesejahteraan subjektif keluarga petani didominasi oleh kesejahteraan tingkat tinggi berdasarkan penilaian indikator kesejahteraan ekonomi.

Indikator kesejahteraan sosial yang terdiri dari tujuh pertanyaan mencakup kepuasan terhadap pendidikan anak, akses informasi (kesehatan dan pertanian), keteribatan pasangan dalam penyuluhan pertanian, pekerjaan, manajemen waktu, terjalin hubungan baik serta dukungan yang diberikan oleh pasangan, anak, saudara, dan tetangga memiliki modus skor 4. Hal ini memberikan pengertian bahwa tingkat kesejahteraan subjektif keluarga petani didominasi oleh kesejahteraan tingkat tinggi berdasarkan indikator kesejahteraan sosial.

Indikator kesejahteraan psikologi yang terdiri dari enam pertanyaan mencakup keaktifan kajian agama, kepuasan terhadap mental diri dan keluarga, 
manajemen stres, perilaku dan kepribadian anak, dalam mengambil keputusan memiliki modus skor=4. Hal ini memberikan pengertian bahwa tingkat kesejahteraan subjektif keluarga petani didominasi oleh kesejahteraan tingkat tinggi berdasarkan penilaian indikator kesejahteraan psikologi.

Indikator kondisi pekarangan yang terdiri dari empat pertanyaan mencakup kepuasan terhadap kondisi tanaman pekarangan, variasi tanaman, pemanfaatan pekarangan dalam menambah pendapatan, dan keberhasilan mengelola pekarangan memiliki modus skor $=3$. Hal ini memberikan pengertian bahwa tingkat kesejahteraan subjektif keluarga petani didominasi oleh kesejahteraan tingkat sedang berdasarkan penilaian indikator kondisi pekarangan.

Indikator kondisi kebun yang terdiri dari empat pertanyaan mencakup kepuasan terhadap pendapatan kebun, penggunaan pestisida, manajemen pestisida, dan kepuasan terhadap cuaca dan iklim memiliki modus skor=4. Hal ini memberikan pengertian bahwa tingkat kesejahteraan subjektif keluarga petani didominasi oleh kesejahteraan tingkat tinggi berdasarkan penilaian indikator kondisi kebun.

Indikator dimensi afektif yang terdiri dari dua pertanyaan mencakup kepuasan dan senang terhadap kondisi saat ini dan kepuasan terhadap keamanan dalam usahatani karet memiliki modus skor=3. Hal ini memberikan pengertian bahwa tingkat kesejahteraan subjektif keluarga petani didominasi oleh kesejahteraan tingkat sedang berdasarkan penilaian indikator dimensi afektif.

Indikator dimensi kognitif yang hanya satu pertanyaan mengenai kepuasan terhadap apa yang telah didapatkan sampai saat ini memiliki modus skor=4. Hal ini memberikan pengertian bahwa tingkat kesejahteraan subjektif keluarga petani didominasi oleh kesejahteraan tingkat tinggi berdasarkan penilaian indikator dimensi kognitif.

Berdasarkan total delapan indikator yang digunakan dalam menilai kesejahteraan subjektif, keluarga petani memiliki modus skor=4. Hal tersebut menunjukkan bahwa kesejahteraan subjektif keluarga petani didominasi oleh kesejahteraan tingkat tinggi.

Hasil penelitian ini berbeda dengan penelitian yang dilakukan oleh Rahma et al. (2015) dimana hasil penelitian mengenai tingkat kesejahteraan subjektif pengetahuan bidang pertanian, serta selalu optimis keluarga petani sebagian besar berada pada tingkat sedang. Perbedaan hasil tersebut dikarenakan keluarga petani sudah merasa puas terhadap kondisi dan kelayakan hidupnya, walaupun tidak untuk semua aspek penilaian dalam kesejahteraan subjektif.

\section{KESIMPULAN}

Berdasarkan hasil penelitian, dapat disimpulkan bahwa rata-rata pendapatan atas biaya tunai usahatani karet yang bermula dari tanaman padi di Kecamatan Abung Surakarta sebesar Rp46.178.978,27/ha/th, sedangkan rata-rata pendapatan atas biaya total sebesar Rp27.821.627,65/ha/th. Tingkat kesejahteraan subjektif keluarga petani sebagian besar berada pada kriteria tinggi.

\section{DAFTAR PUSTAKA}

Alhidayad. 2008. Analisis pendapatan petani karet di Desa Pulau Pandan Kecamatan Limun Kabupaten Sorolangun. Skripsi. Fakultas Ekonomi Program Ekstensi Universitas Jambi. http://www.anakciremai.com/2016/ 03/skripsi-ekonomi-analisis-pendapatan.htm 1. [8 Desember 2018].

Armin. 2017. Studi tingkat pendapatan petani sebelum dan sesudah konversi lahan pertanian ke perkebunan kelapa sawit di Desa Pakawa Kecamatan Pasangkayu Kabupaten Mamuju Utara. e-Jurnal Katalogis, 5 (3):100 - 108. https://www. neliti.com/id/publications/190825/studitingkat-pendapatan-petani-sebelum-dansesudah-konversi-lahan-pertanian-ke. November 2018].

Astuti UP, Wibawa W dan Ishak A. 2011. Faktor yang mempengaruhi alih fungsi lahan pangan menjadi kelapa sawit di Bengkulu. Forum Penelitian, 190-195. http://repository unib.ac.id/128/. [13 November 2018].

BPS [Badan Pusat Statistik]. 2018. Kontribusi Subsektor Pertanian terhadap Sektor Pertanian Periode 2016. https://www.bps. go.id/publication/2018.[20 November 2018].

BPS [Badan Pusat Statistik] Kabupaten Lampung Utara. 2016. Kabupaten Lampung Utara dalam Angka 2016. https://lampungutara kab. bps.go.id/publikasi.html. [20 November 2018].

BPS [Badan Pusat Statistik] Kecamatan Abung Surakarta. 2011. Kecamatan Abung Surakarta dalam Angka 2010. 
https:// lampungutarakab.bps.go.id/publication.html?page=14. [20 November 2018]. 2017.

Kecamatan Abung Surakarta dalam Angka 2017. https://lam- pungutarakab.bps.go.id/ publication/2017/kecamatan-abung-suraka rta-dalam-angka-2017. html. [20 November 2018].

Damanik S, Syakir M, Tasma M, dan Siswanto. 2010. Budidaya dan Pasca Panen Karet. Pusat Penelitian dan Pengembangan Perkebunan. Bogor.

Diener D. 2000. Subjective Well Being: The Science of Happiness and a Proposal for a National Index. American Psychologist, 55 (1) : 34-43. http:/psycnet.apa.org. [7 Desember 2018].

Irawan B. 2005. Koversi Lahan Sawah Menimbulkan Dampak Negatif Bagi Ketahanan Pangan dan Lingkungan. Pusat Analisis Sosial Ekonomi dan Kebijakan Pertanian. Bogor.

Kementerian Pertanian. 2017. Outlook Komoditas Pertanian Sub Sektor Perkebunan Karet. http://epublikasi.pertanian.go.id/arsipoutlook/75-outlook-perkebunan/549outlook-karet-2017. [28 November 2018].
Mardiana R, Abidin Z, dan Soelaiman A. 2014. Pendapatan dan kesejahteraan petani karet rakyat di Kecamatan Bumi Agung Kabupaten Way Kanan. JIIA, 2 (3):239-245. http://jurnal.fp.unila.ac.id/index. php/JIA/ article/view/806. [1 Desember 2018].

Rahma A, Puspitawati H, dan Herawati T. 2015. Pengaruh gender dan pemeliharaan lingkungan mikro terhadap kesejahteraan subjektif keluarga petani dataran tinggi. Jurnal Ilmu Keluarga \& Konsumen, 8 (2):69-79. http://journal.ipb.ac.id/index. php/ jikk/article/view/10020. [7 Desember 2018].

Sari AM, Ismono RH, dan Kasymir E. 2015. Alih Fungsi lahan padi menjadi karet di daerah irigasi way rarem Pulung Kencana Kabupaten Tulang Bawang Barat. JIIA, 3 (4):336-344. http://jurnal.fp.unila.ac.id/index .php/JIA/ article/view/1082. [14 November 2018].

Soekartawi. 2002. Analisis Usahatani. UI Press. Jakarta.

Sugiarto. 2003. Teknik Sampling. Gramedia. Jakarta.

Triwijoso dan Utami S. 1995. Pengetahuan Umum Tentang Karet Hevea. Balai Penelitian Teknologi Karet Bogor. Bogor. 